\title{
Gender Perspective in Bugis Makassar
}

\author{
Musdalia Mustadjar \\ Universitas Negeri Makassar \\ Makassar, Indonesia
}

\author{
Gufran Darma Dirawan \\ Universitas Negeri Makassar \\ Makassar, Indonesia
}

\begin{abstract}
The purpose of this study was to determine the gender understanding and application in Bugis Makassar family. In addition, this study also revealed guidelines Bugis Makassar family life. The research method used Qualitative in a case study. Sampling technique used purpossive with predetermined criteria. The research was done in Universitas Negeri Makassar. The researcher apply as an instrument. Data collection techniques are observation, interviews, and documentation. The data analysis technique is descriptive qualitative measures of data reduction, data presentation and conclusion. The conclusion of the research is that the couple understand and interpret gender equality as proportional equality in decision-role based on a way of life. The guidelines are based on the value of Bugis Makassar culture, namelySiri' (Dignity),Pangaderreng (customs), Sipakatau (mutually respect), Sipakalebbi' (mutually honor), and Teppe' (belief). The implementation of gender equality family Bugis Makassar framed by cultural and religious values. In Makassar Bugis family, gender equality form shown in the dual role of women public sector, with awareness and specific goals without forgetting obligations as a wife for her husband, as a mother to her children, as well as community members.
\end{abstract}

\section{Keywords- Gender, Culture in Bugis Makassar, Dual Role}

\section{INTRODUCTION}

In general,the gender concept of the West is equality and equal partnership between men and women in all aspects [1]. In contrast to the concept of gender in the family Bugis Makassar, gender is a deal and suitability proportionally in making roles between men and women, especially married couple based on the rule of life Bugis Makassar, namely Siri' (Dignity), Pangaderreng, (customs), Pangadakkang (Customs), Sipakatau (respect), Sipakalabbi' (honor), and Teppe' (Confidence).

The dimensional way of life colored by cultural values and religious values [2]. This value is the motivation and guidance for families Bugis Makassar in implementing gender equality in the social environment. For example, a husband in the family Bugis Makassar feels low self-esteem when insulted his wife (Siri'). A husband also must nurture and protect her as a hereditary habit (Pangaderreng).

As a husband and wife should respect each other and have the same rights and obligations (SipakatauSipakalebbi'). Other than that, husband and wife and their status equal before God Almighty (Teppe'). These are the values of local wisdom in Bugis Makassar family. South Sulawesi women today, especially the Bugis-Makassar are more open to interpret the values of culture. Their quantity and quality are not only involved in the domestic realm but also active in the public sphere.

In fact, many of them still do activities with multiple roles in their home environment, so that the status as a wife, a housewife, a friend for their children, as well as elements of community members can be acted properly. It is of course supported by the high level of education that can be obtained by women, which in turn helped contribute to women's mindset especially Bugis Makassar in South Sulawesi as a contribution to the emancipation of women and gender equality and social change today.

\section{METHOD}

The research method used Qualitative in a case study. Sampling technique used purposive with predetermined criteria. The research was done in Universitas Negeri Makassar. The researcher applies as an instrument. Data collection techniques are observation, interviews, and documentation. The data analysis technique is descriptive qualitative measures of data reduction, data presentation, and conclusion.

\section{III.RESULTS}

\section{A. Principles of Human in Bugis Makassar Perspective}

Cultured value is shifts in understanding and implementing the concept and principles of ade' (customs), and Bugis Makassar culture really is. In human life of Bugis Makassar, siri'is the principal element in themselves. There is no single value of the most valuable to be defended and preserved on earth than siri'. Bugis Makassar perspective, siri'is their soul, their pride, and their dignity. Therefore, in order to uphold and defend the siri' is considered to be contaminated or polluted by others, then the Bugis-Makassar man is willing to sacrifice anything, including the most precious souls for the sake siri' in their lives [3].

The value siri' is a sacred value of Bugis Makassar society. The culture of siri' should be maintained on the corridor $a d e^{\prime}$ (customs), and applying Islamic rule in practice it. When viewed as a whole, the society in Bugis Makassar is a man full of principles and values ade' (customs) and the Islamic rule in running their lives. They are able to uphold these principles inreflected of Bugis Makassar man who fell from the heaven (to Manurung) to provide exemplary in bringing social rules and norms of the earth [4].

\section{B. Women value Bugis Makassar}

As husbands, they already know and understand the value of women in the family Bugis Makassar, namely as Indo' Ana' (mother), as Pattaro Pappole Asalewengeng, as Repo'riatutui Siri'na (protect family honor). There is three value of women in the application of the family Bugis Makassar gender, that is awoman as Indo Ana' (mother); women as Pattaro Pappole Asalewangeng; and women as Repo 'Riatutui Siri'na; [3], [5]. Indo 'Ana' is meant that women who give birth to offspring. Women as a mother is 

income)meant that women who manage finances and determine prosperity and happiness in the household. Repo Riatutui Siri'na (protect family honor) meant that women who determine the level of the dignity of the family. Therefore, women should be acknowledged, loved, loved, and cared for. Therefore, women are thought of as eggs, if fractured it will rot and discarded. The third value is hinted a number of provisions which must be a woman, especially Bugis Makassar South Sulawesi to be considered as the ideal woman.

The development and the demands of the times indicate a change which has implications for the advancement of the role of women in all areas of gender equality. Women's South Sulawesi Bugis Makassar is now more open, especially in interpreting the values of culture. In terms of quantity and quality, women are not only involved in the domestic domain but also active in the public sphere. Many of them still do activities with multiple roles in their home environment. This is supported by the level of education held by women. It also contributes to the mindset of women, especially women of South Sulawesi Bugis Makassar.

The right to earn a living for the continuity of family life not only can be done by men only. It can also be done by a woman, as a wife and a daughter. All things were made by women cannot be separated from consideration and forethought. This is based on the opinion of the rationality of action Weber, where everyone does the actual action suit its intended purpose and are expected with full awareness.

Women in the family Bugis Makassar double play on the basis of a rational purpose, rational values, and effective action. It is based on the habits that arise from the established practices, and respect for existing authority. Thus, Bugis Makassar women have a particular meaning in implementing gender equality in the family to reach equilibrium in the household. Rationalization of communicative action frees communication plays an important role of dominance, liberate and open communication. Rationalization herein includesemancipation and remove the barriers of communication [6].

\section{Meaning of Value of Women, Tudang Sipulung, Sipakatau, and Sipakalebbi}

Communicative action in the local wisdom culture that is still awake is Tudang Sipulung (seated together or deliberation), and sipakatau (mutual respect), and sipakalebbi' (mutual respect). This is done by men and women in every activity, deliberation, and decision-making. This habit is a form of sit together to discuss the issues that are actually in any field. The role of women as educators with the function of the agent of changes, has the basics of faith, intellect, integrity and strong professionalism in building a new generation. When the family members and the community have benefited from the role of women, so naturally women will get social legal. Women will be appreciated and heard in a deliberation and would have no discrimination. This situation opens a space for selfactualization in terms of sharing forum meeting. Marginalization, stereotypes, and violence can be minimized when women understand their role.

TABLE I.

CONCLUSIONS THE RESULTS OF 5 INFORMANT INTERVIEW MARRIED BUGIS MAKASSAR ON CULTURAL VALUES.

\begin{tabular}{|c|c|c|}
\hline Culture value & \begin{tabular}{|c|} 
Implementation \\
Guidelines for \\
Living
\end{tabular} & Information \\
\hline Siri' & Career & $\begin{array}{l}\text { Meaning of siri' is } \\
\text { applied as the highest } \\
\text { cultural values ro } \\
\text { preserve the views of } \\
\text { others towards oneself } \\
\text { and self-identity as a } \\
\text { lecturer and civil servant } \\
\text { social interaction }\end{array}$ \\
\hline Panngaderreng & - & - \\
\hline \multirow[t]{2}{*}{ Sipakatau } & $\begin{array}{l}\text { Husband and } \\
\text { Wife }\end{array}$ & $\begin{array}{l}\text { Appointment attitude } \\
\text { with respect, obey, and } \\
\text { obey the commands of } \\
\text { her husband, but not } \\
\text { oppression } \\
\text { discrimination, but rather } \\
\text { a form of affection }\end{array}$ \\
\hline & Career & $\begin{array}{l}\text { Appointment of respect } \\
\text { for fellow lecturers, } \\
\text { students, faculty and the } \\
\text { community, superiors, } \\
\text { peers and subordinates. }\end{array}$ \\
\hline Sipakalebbi & $\begin{array}{l}\text { Husband and } \\
\text { Wife }\end{array}$ & $\begin{array}{l}\text { Appreciate all the } \\
\text { decisions have been } \\
\text { taken in arranging a } \\
\text { family member, a good } \\
\text { husband / wife for their } \\
\text { understanding }\end{array}$ \\
\hline $\begin{array}{l}\text { Teppe' } \\
\text { Religious } \\
\text { Values }\end{array}$ & Children & $\begin{array}{l}\text { Instilling values of } \\
\text { monotheism and provide } \\
\text { a variety of information } \\
\text { about prophet } \quad \text { Nabi } \\
\text { Muhammad } \\
\text { exemplary accordance } \\
\text { pillars of Islam and the } \\
\text { pillars of faith }\end{array}$ \\
\hline
\end{tabular}

TABLE II. CONCLUSIONS THE RESULTS OF 5 INFORMANT INTERVIEW MARRIED ON DUAL ROLE.

\begin{tabular}{|l|l|l|}
\hline $\begin{array}{c}\text { Dual Role of } \\
\text { Women }\end{array}$ & $\begin{array}{c}\text { Implementation } \\
\text { of Dual Role of } \\
\text { Women }\end{array}$ & \multicolumn{1}{|c|}{ Information } \\
\hline Spirit & Wife & $\begin{array}{l}\text { As the wife always gives } \\
\text { spirit to her husband and } \\
\text { children to create } \\
\text { harmony, happy to } \\
\text { cooperate in the work } \\
\text { both at home and outside } \\
\text { the home fosters love } \\
\text { and attention to her } \\
\text { husband and children. }\end{array}$ \\
\hline
\end{tabular}


Г.

\begin{tabular}{|l|l|l|}
\hline $\begin{array}{c}\text { Dual Role of } \\
\text { Women }\end{array}$ & $\begin{array}{l}\text { Implementation } \\
\text { of Dual Role of } \\
\text { Women }\end{array}$ & \multicolumn{1}{|c|}{ Information } \\
\hline Motivation & Wife & $\begin{array}{l}\text { As a husband and wife are } \\
\text { always motivated to work } \\
\text { hard to get a decent job title, } \\
\text { help increase revenue, } \\
\text { motivate the husband's } \\
\text { responsibility in accepting } \\
\text { the mandate, happy doing } \\
\text { the job occupied and create a } \\
\text { harmonious family } \\
\text { environment }\end{array}$ \\
\hline Achievement & Wife & $\begin{array}{l}\text { As the wife always } \\
\text { recommends to my husband } \\
\text { and children to success in } \\
\text { working hard through a good } \\
\text { performance to support the } \\
\text { strengthening of the } \\
\text { economy without neglecting } \\
\text { the care of children as a key } \\
\text { task in the family. }\end{array}$ \\
\hline
\end{tabular}

To obtain a social legal, women will be trying to gain access and control at all levels of policy. Women are required to have intelligence look to seize the strategic space access by taking into account local resources are owned by their respective regions in improving the quality of human resources (self-education). Women in any profession is obliged to mutually work together to uplift the lives of the midst of growing globalization.

Table 1, shown that the cultural values that guide the lives of informants IK and MS him as Bugis family. In this case, panngaderreng less visible yet implemented, given the informant IK families their children are married yet. Cultural values siri', sipakatau, sipakalebbi and teppe' dominant implemented in living and family life.

Table 2, shown that the implementation of women's multiple roles of informants IK understand that dual role in giving spirit to her husband and children is very important. It is always shown to create harmony, happy to cooperate in the work both at home and outside the home, fosters love and attention to her husband and children. Conversely, too, the husband and children must be given support.

\section{CONCLUSION}

Based on the results, it can be concluded that the couple understands and interpret gender equality as proportional equality in decision-role based on a way of life. The guidelines are based on the value of Bugis Makassar culture, namely Siri' (Dignity), Pangaderreng (Customs), Sipakatau (Mutually Respect), Sipakalebbi' (Mutually Honor), and Teppe' (belief).

Implementation of gender equality family Bugis Makassar framed by cultural values and religious values. In Makassar Bugis family, gender equality form is shown in the dual role of women public sector, with awareness and specific goals without forgetting obligations as a wife for her husband, as a mother to her children, as well as community members.

\section{REFERENCES}

[1] B. J. Risman, 'Gender as a social structure theory wrestling with activism', Gend. Soc., vol. 18, no. 4, pp. 429-450, 2004.

[2] J. Abdussamad, H. Akib, and J. Paramata, 'Effect of Transformational Leadership and Organizational Culture on Employee Performance toward the Department of Education, Youth and Sports Gorontalo Province, Indonesia', Int. J. Acad. Res., vol. 7, no. 1, 2015.

[3] Mattulada, Latoa: satu lukisan analitis terhadap antropologi-politik orang Bugis:(a descriptive analysis of the political anthropology of the Buginese). Universitas Indonesia., 1975.

[4] M. Mahmud, 'Language and gender in English language teaching', TEFLIN J., vol. 21, no. 2, p. 172, 2010.

[5] C. Pelras and Pelras, The Bugis. JSTOR, 1996.

[6] G. Ritzer, 'Sosiologi: Ilmu Pengetahuan Berparadigma Ganda (Sociology: A Multiple Paradigm Science)'. Jakarta: Rajawali Press, 1985. 